\title{
Hubungan Status Gizi dan Status Hidrasi dengan Fungsi Memori Jangka Pendek Anak Usia Sekolah
}

\section{Correlation of Nutritional and Hydration Status and The Function of Short- Term Memory in School-Age Children}

\author{
Biyanti Dwi Winarsih*, Yayuk Fatmawati, Sri Hartini \\ Sekolah Tinggi Ilmu Kesehatan Cendekia Utama Kudus \\ Jl. Lingkar Raya Kudus - Pati Km. 5, Jepang, Mejobo, Kudus. 59382. Jawa Tengah \\ *Email: zidanina1706@gmail.com
}

\begin{abstract}
Short-term memory in school-age children is significant in the learning process and academic ability improvement. Adequate intake of nutrients and body fluids are needed to accelerate brain performance so that children have optimum memory function. A preliminary study on short term memory of students in SD N Gembong 2, Pati Regency showed that some students experienced a decrease in short-term memory. The objective of this study was to analyze the correlation between nutritional status and nutritional status with children's short-term memory. This study used a correlational design and involved 52 students from 4th - 6th grade in elementary school. The measurement of hydration status used urine specific gravity, while short-term memory was measured using a digit span test. Then, the Chi-Square test was applied to analyze the data. This study result showed that more than half of children had normal nutritional status, good hydration status and normal short-term memory. Furthermore, nutritional status and hydration status were associated with children's short-term memory. Parents should provide more attention to their children's nutritional and fluid needs, by 1) the children are getting used to taking breakfast before going to school and 2) parents provide meals and drinks from home for their children.
\end{abstract}

Keywords: hydration status, nutritional status, short-term memory

\begin{abstract}
ABSTRAK
Memori jangka pendek pada anak usia sekolah sangat berpengaruh terhadap proses belajar dan upaya peningkatan kemampuan akademik. Asupan nutrisi dan cairan tubuh yang cukup dibutuhkan untuk meningkatkan kerja otak sehingga fungsi memori anak lebih optimal. Data awal penelitian terkait memori jangka pendek anak di SD N Gembong 2 Pati menunjukkan sebagian anak mengalami penurunan memori jangka pendek. Tujuan penelitian ini adalah menganalisis hubungan status gizi dan status nutrisi dengan memori jangka pendek anak. Metode penelitian korelasional dengan jumlah sampel 52 responden anak kelas 4-6 SD. Pengumpulan data status gizi melalui pengukuran berat badan dan tinggi badan. Pengukuran status hidrasi menggunakan pemeriksaan berat jenis urine dan memori jangka pendek menggunakan test digit span. Analisa menggunakan chi square. Hasil penelitian menunjukkan sebagian besar anak mempunyai status gizi normal, status hidrasi baik dan memori jangka pendek yang normal. Terdapat hubungan antara status gizi dan status hidrasi dengan memori jangka pendek anak. Orang tua sebaiknya lebih memperhatikan kebutuhan nutrisi dan cairan anak dengan cara: 1) membiasakan sarapan sebelum berangkat sekolah; dan 2) pada saat anak ke sekolah lebih baik dibawakan bekal makanan dan minuman.
\end{abstract}

Kata kunci : status hidrasi, status nutrisi, memori jangka pendek

\section{PENDAHULUAN}

Kemampuan mengingat kembali sesuatu yang telah didengar, dilihat, atau suatu pengalaman sebelumnya mempunyai pengaruh besar terhadap proses belajar mengajar dan peningkatan kemampuan secara akademis pada anak (Prasetyo \& Saputra, 2017). Daya ingat, baik memori jangka panjang maupun jangka pendek akan berpengaruh terhadap prestasi akademis. 
Anak dengan ingatan yang baik akan mudah dan cepat menerima atau memahami informasi (Apriyanto, 2014).

Kemampuan mengingat atau daya pikir merupakan suatu kemampuan seseorang dalam menerima informasi, menyimpan, dan mengingat kembali pesan yang telah diterima, serta tanggapan pemahaman seseorang terhadap suatu kejadian atau pesan. Daya ingat atau memori setiap anak berbeda. Beberapa penelitian menyebutkan daya ingat dipengaruhi oleh status gizi dan status hidrasi.

Status gizi yang baik akan mengoptimalkan fungsi memori sehingga prestasi mengarah ke cukup dan baik (Abdullah \& Norfai, 2019). Pemenuhan asupan gizi anak dapat diketahui dari perhitungan status gizi yang terbagi dalam gizi obesitas, gizi lebih, normal, gizi kurang, dan gizi buruk. Kelebihan gizi dapat memengaruhi memori jangka pendek anak. Sebagian besar anak dengan obesitas dan gizi lebih memiliki memori jangka pendek yang rendah. Sementara itu, anak dengan gizi kurang juga berpotensi mengalami masalah pada kemampuan belajar dan mengingat sesuatu (Hartini \& Winarsih, 2014). Obesitas menyebabkan kelebihan lemak pada tubuh. Selain itu terjadi atropi susunan syaraf pusat, yaitu grey matter terutama pada area hippocampus yang mengatur kemampuan mengingat seseorang (Palupi, Sulaeman, \& Ploeger, 2013).

Status hidrasi atau kecukupan jumlah cairan dalam tubuh juga berpengaruh terhadap memori anak. Kekurangan air sebesar 1\% dari total berat badan akan menyebabkan gangguan kinerja otak dan kecakapan berfikir. Selanjutnya, kekurangan cairan tubuh sebanyak $2 \%$ dari berat badan dapat memicu pengurangan pemusatan pemikiran dan perhatian serta kemampuan mengingat dalam rentang waktu yang singkat. Kondisi ini akan menyebabkan penurunan kecerdasan anak dan menganggu kegiatan belajar mengajar yang harus dijalani oleh anak. Anak dengan kecukupan minum yang cukup memiliki konsentrasi lebih baik dibanding anak yang mengalami kekurangan minum (Kusumawardani \& Larasati, 2020). Penelitian lain membuktikan status hidrasi yang kurang atau dehidrasi akan memengaruhi penurunan konsentrasi sehingga menurunkan daya ingat (Sudrajat, Mexitalia, \& Rosidi, 2019). Penelitian oleh Winarsih, Fatmawati, \& Hartini (2020) menyatakan anak yang mengonsumsi air mineral lebih banyak cenderung memiliki fungsi memori yang lebih baik. Hasil tersebut didapat pada periode 30 menit setelah anak mengonsumsi $200 \mathrm{ml}$ air.

Data awal penelitian terkait memori jangka pendek anak di Sekolah Dasar Negeri 2 Gembong, Kabupaten Pati menunjukkan sebagian anak mengalami penurunan memori jangka pendek. Sebagian anak lainnya hanya mampu menjawab setengah dari jumlah soal tes. Sebagian anak juga menyatakan bahwa mereka malas untuk sarapan dan minum di pagi hari sebelum berangkat sekolah. Saat di sekolah, terdapat anak yang membawa bekal makan dan minum, namun sebagian lainnya tidak membawa bekal. Berdasarkan latar belakang, tujuan penelitian adalah 1) menggambarkan status gizi, status hidrasi, dan fungsi memori jangka pendek anak dan 2) menganalisis hubungan status nutrisi dan status hidrasi dengan fungsi memori jangka pendek anak usia sekolah.

\section{TINJAUAN PUSTAKA}

\section{Anak Usia Sekolah}

Anak usia sekolah dasar berada pada rentang usia 6-12 tahun. Anak-anak pada masa tersebut mulai dilatih tanggung jawab untuk mengatur dirinya sendiri serta melakukan tindakan yang bermanfaat dan berfungsi untuk dirinya sendiri. Mereka harus mampu membina hubungan yang baik dengan kedua orang tua, teman di sekolah maupun di rumah, dan orang lain seperti tetangga atau kerabat lainnya. Pada masa sekolah, anak-anak mendapatkan ilmu dasar dan pengetahuan agar mampu meraih kesuksesan dalam menyesuaikan diri terhadap permasalahan yang akan dihadapi pada masa dewasa dan mendapatkan kemampuan khusus sesuai dengan harapannya. Semua hal tersebut akan didukung oleh perubahan kemampuan intelektual atau kognitif (Wong, 2009). 
Perkembangan yang dilalui anak, yaitu perkembangan fisik, sosio emosional, bahasa, dan kognitif. Perkembangan kognitif anak menunjukkan kemampuan anak dalam berpikir kritis, menghafal, mengingat dan memahami serta menganalisis. Kemampuan kognitif anak akan semakin meningkat seiring dengan penambahan usia. Anak akan mampu berpikir dari hal yang mudah ke hal yang sulit. Selain itu, pengetahuan anak akan meningkat setelah melakukan aktivitas belajar untuk menambah wawasan dan menyelesaikan masalah yang dihadapi yang diterapkan dalam proses belajar mengajar (Bujuri, 2018).

Perubahan kognitif pada anak usia sekolah dasar berupa perubahan untuk mengoptimalkan cara berfikir berdasarkan logika maupun penalaran yang baik. Perubahan ini berkaitan dengan kemampuan menganalisis objek secara nyata, bukan berdasarkan khayalan. Selanjutnya, perkembangan kognitif anak menurut Piaget terdiri dari beberapa tahapan yang disesuaikan dengan usia anak, yaitu: (1) tahap sensori-motorik (0-2 tahun), perkembangan meningkat dilihat dari kemampuan kegiatan motorik dan persepsi sederhana; 2) tahap praoperasional (2-7 tahun), anak mampu menggunakan bahasa dan mengembangkan konsep secara sederhana; (3) tahap operasional konkret (7-11 tahun), anak sudah memiliki kecakapan berfikir logis pada benda yang bersifat konkret; dan (4) tahap formal operation (11-15 tahun), anak sudah mampu berpikir abstrak dan logis menggunakan induktif dan deduktif (Mu'min, 2013).

\section{Konsep Memori}

Memori merupakan konsep kinerja otak untuk menyimpan pesan yang didapatkan dari panca indra. Memori menjadi dasar dalam menentukan kemampuan neurokognitif seseorang. Kemampuan tersebut terdiri dari membuat sandi, menyimpan informasi, dan mengembalikan informasi. Selain itu, memori juga sebagai tempat menganalisis informasi sebelum disampaikan kepada orang lain. Seseorang akan berusaha menangkap pesan dan menyusun pengertian atau pemahaman dengan cara mengasah daya ingat sesuai hal-hal yang telah didapatkan atau ditangkap oleh memori sehingga orang akan bisa mengerjakan sesuatu berdasarkan hasil logikanya (Hastjarjo, 2008).

Pengukuran atau penilaian memori jangka pendek dilakukan menggunakan penilaian rentang memori (memory span), yaitu dengan menjumlah item yang dapat dijawab dengan tepat dengan mengulang materi pertanyaan yang disampaikan oleh pemeriksa. Materi yang dipakai dalam penilaian ini adalah serangkaian angka secara acak serta tidak berdasarkan aturan kelipatan, penjumlahan, pengurangan maupun pembagian. Test penilaian memori berbeda dengan test intelegensi atau kemampuan kemampuan dan potensial akademik yang biasa dilakukan berupa angka atau simbol dengan ketentuan khusus (Desmita, 2009).

\section{Pengukuran Memori Jangka Pendek}

Memori jangka pendek anak merupakan suatu komponen struktur jaringan pada sistem indra manusia yang berfungsi untuk melihat, mendengarkan, merasakan, dan membaui. Aktivitas struktur jaringan melakukan dua fungsi, yaitu mempertahankan informasi dalam waktu yang singkat dan melanjutkan dalam periode waktu selanjutnya untuk membawa memori selanjutnya. Memori jangka pendek memiliki kapasitas yang kecil yaitu tujuh angka namun mempunyai peranan yang sangat besar dalam aktivitas penyimpanan informasi. Waktu yang relatif singkat untuk pencatatan ini, membutuhkan proses pengorganisasian yang baik. Anak akan lebih sering menggunakan indra untuk proses interaksi. Periode mengingat kembali dimulai dari pesan diterima sampai proses merespon atau menanggapi. Anak dilatih dengan menyebut suatu angka atau huruf secara acak dengan metode mundur yaitu diminta untuk menyebutkan kembali angka yang telah disampaikan dimulai dari angka yang paling terakhir. Tujuan pengulangan pesan untuk disampaikan kembali setelah didengar atau didapatkan adalah agar informasi 
tidak mudah hilang dari memori. Kondisi ini harus didukung dengan struktur neurokognisi yang baik, tidak ada penyakit maupun kerusakan pada organ otak (Bhinnety, 2008)

Tes Digit Span adalah tes yang digunakan untuk mengukur kemampuan memori jangka pendek anak yang terdiri dari dua bagian, yaitu mengingat angka maju dan angka mundur. Masing-masing bagian tes terdiri dari delapan item angka yang dimulai dari dua hingga sembilan digit. Setiap item terdiri dari dua deretan angka yang dibagi menjadi subitem A dan B. Waktu yang dialokasikan untuk mengulang angka dari setiap item adalah satu menit. Skor total apabila seluruh item dijawab dengan benar adalah 32 . Makin tinggi skor yang diperoleh anak maka fungsi memori jangka pendek makin baik (Hartini \& Winarsih, 2014). Setiap subtes Digit Span Forward terdapat delapan item yang masing-masing item diujikan dalam dua kali percobaan. Subtes item pertama terdiri dari dua digit angka dan item selanjutnya terdiri dari seri digit angka yang lebih tinggi. Pada percobaan pertama item tujuh terdapat pengulangan dua digit angka yang sama.

Setiap percobaan, penguji menyebutkan beberapa angka sesuai urutan dan segera setelahnya anak diminta untuk menyebutkan kembali angka yang sama persis dengan yang disebutkan oleh penguji. Apabila gagal dalam dua kali percobaan dalam suatu seri tertentu, maka dilanjukan ke tes Digit Span Backward. Item yang digunakan pada tes Digit Span Backward sama dengan tes Digit Span Forward namun dengan deretan angka yang berbeda. Setiap percobaan, penguji menyebutkan beberapa angka sesuai dengan yang tertulis pada lembar pengujian, kemudian dengan segera meminta anak diminta untuk mengulang untuk angkaangka yang telah disebutkan penguji, dimulai dari angka yang disebutkan paling akhir ke yang awal. Misalnya penguji menyebutkan angka 7-2 dan anak harus menjawab 2-7. Apabila anak berhasil dalam percobaan maka lanjutkan test berikutnya. Seorang anak yang mempunyai nilai Memory Span lebih besar akan mampu mengingat kembali berbagai stimulan atau rangsangan yang lebih dan memberi manfaat dalam upaya pelaksanaan tugas perkembangan intelektual (Putranto, 2009).

Peningkatan memori berkaitan erat dengan cara bagaimana anak belajar dengan baik, bagaimana anak dapat mengolah pesan atau informasi untuk dapat disampaikan kembali kepada orang lain. Cara yang mudah untuk peningkatan memori adalah dengan belajar angka secara sederhana dan sering diberikan stimulasi melalui permainan. Memori yang terstimulasi dengan baik sangat memungkinkan anak menyimpan atau meretensi informasi dalam kondisi anak yang sehat (Ningtyas, 2018).

\section{Faktor yang Memengaruhi Memori}

Memori jangka pendek dan jangka panjang anak dipengaruhi oleh faktor internal dan eksternal. Faktor internal yaitu faktor fisiologis dan psikologis. Faktor fisiologis terdiri dari keadaan tubuh yang sehat, konsumsi makanan yang cukup nilai gizinya, asupan minum yang sesuai kebutuhan, serta fungsi indra yang baik. Faktor eksternal yaitu faktor lingkungan terdiri dari lingkungan sosial di masyarakat, keluarga, sekolah dan lingkungan nonsosial yaitu penyediaan sarana prasarana belajar (Musdalifah, 2019).

\section{Status Gizi}

Status gizi merupakan kondisi kesehatan seseorang yang dipengaruhi oleh asupan gizi dan absorbsi dalam tubuh. Status gizi yang baik dipengaruhi oleh jumlah intake nutrisi yang masuk ke dalam tubuh. Pola makan anak akan menentukan status gizi anak. Anak dengan pola makan berlebihan lebih rentan mengalami gizi lebih. Kelebihan gizi akan berdampak pada penurunan kecerdasan karena malas melakukan aktivitas. Sebaliknya, anak dengan gizi kurang atau stunting akan mengalami perlambatan pertumbuhan dan perkembangan (Rahmawati \& Marfuah, 2016). Gizi terwujud dalam berbagai komponen yang menunjukkan angka dan diintepretasikan dalam tolak ukur untuk menetapkan status gizi obesitas, normal, dan kurang (Desmita, 2009). Status gizi anak dipengaruhi asupan atau konsumsi zat nutrien dan kebutuhannya. Kebutuhan gizi disesuaikan 
dengan umur, jenis kelamin, kegiatan atau pekerjaan, massa tubuh, serta tinggi badan. Apabila asupan nutrisi melebihi kebutuhan maka tubuh menyimpannya dalam bentuk glikogen dan akan digunakan ketika tubuh mengalami kekurangan nutrisi. Sebaliknya, apabila asupan nutrisi kurang dari kebutuhan, cadangan lemak dalam tubuh akan diubah menjadi energi (Wiyono \& Harjatmo, 2019). Anak yang mengalami malnutrisi dapat mengalami gangguan daya ingat. Hal ini disebabkan tidak terpenuhinya kebutuhan nutrisinya, khususnya otak untuk melakukan fungsinya (Astina, 2012). Diet ideal menurut kebutuhan tubuh sebanyak 1.600-2.800 kkal/hari. Rata-rata anak mengonsumsi karbohidrat dan protein 2.100 kkal dan akan meningkat saat melakukan aktivitas seperti sekolah. Selain kebutuhan energi dan protein, asupan yang harus terpenuhi adalah mineral dan vitamin. Mineral akan membantu menjaga fungsi jantung, otot, serta proses pembekuan darah. Orang tua menjadi kunci utama dalam pemenuhan makan baik dari segi kualitas dan kuantitas makanan (Maulina, Subekti, \& Yulia, 2019).

Selain kecukupan gizi, tubuh juga memerlukan keseimbangan energi sehingga proses metabolismenya berlangsung secara normal. Ketidakseimbangan antara energi yang masuk dalam bentuk makanan dengan energi yang keluar dapat menyebabkan kelebihan gizi atau obesitas (Yuliati, Kandarina, \& Sudargo, 2018). Berat badan berlebih berpotensi memengaruhi terjadinya perubahan memori jangka pendek, yaitu penurunan memori (Hartini \& Winarsih, 2014).

\section{Status Hidrasi}

Asupan cairan lebih sedikit dari kebutuhan cairan harian pada seseorang akan berakibat tidak baik bagi tubuh. Beberapa masalah yang dapat muncul akibat kondisi kekurangan cairan atau dehidrasi antara lain, penurunan laju metabolisme tubuh, kerusakan ginjal, peningkatan kerja jantung, penurunan penghantaran oksigen dan nutrisi ke jaringan otak yang dapat memicu penurunan kemampuan pemusatan perhatian saat belajar (Yuliati dkk., 2018).
Kekurangan konsumsi cairan harian dapat memicu terjadinya gangguan atau masalah kesehatan, seperti masalah kognitif maupun motorik. Dehidrasi pada anak sekolah akan menurunkan fisiologi tubuh, menurunkan kualitas belajar, dan mengurangi konsentrasi. Tingginya aktivitas anak sekolah memungkinan terjadinya kekurangan asupan cairan. Anak terlalu fokus pada kegiatannya sehingga lupa untuk minum. Anak yang sudah mendapat informasi pentingnya minum akan menambah konsumsi cairan terutama pada saat siang hari (Sari, Rosya, \& Wahyuni, 2019).

Seseorang yang mengalami kekurangan cairan akan menunjukkan dampak yang kurang baik bagi tubuh. Masalah kesehatan yang dapat muncul, antara lain konstipasi, urolitiasis, kekakuan pada otot, infeksi pada perkemihan, dan tidak elastisitas pada kulit. Dampak negatif lain yang dapat timbul akibat dehidrasi adalah menurunnya daya tahan tubuh, daya ingat, dan kemampuan intelektualitas. Kekurangan cairan sebesar $1 \%$ dari berat badan dapat mengganggu fungsi otak dan potensi berfikir. Sementara itu, kekurangan cairan 2\% dari berat badan kemungkinan menyebabkan penurunan perhatian, kemampuan memfokuskan informasi, konsentrasi, serta kemampuan mengingat sesuatu. Kondisi tersebut akan berdampak buruk pada kecerdasan dan pendidikan anak (Santoso, Siregar, \& Pardede, 2011). Dehidrasi pada anak yang tidak segera ditangani berpotensi mengganggu fungsi kognitif, seperti penurunan konsentrasi, kecermatan, dan memori jangka pendek (Pertiwi, 2015).

Proses atau sistem melakukan retensi pesan atau informasi di dalam otak bergantung pada kemampuan konsentrasi atau atensi anak. Selain itu, kemampuan atensi juga dipengaruhi oleh pemenuhan kebutuhan cairan tubuh dan nutrisi yang cukup. Anak yang tidak mengalami dehidrasi memiliki atensi yang lebih baik dibandingkan anak yang mengalami dehidrasi. Cairan tubuh sangat berperan dalam proses metabolisme tubuh yang menghasilkan energi untuk kerja seluruh jaringan tubuh termasuk otak (Bahrudin \& Nafara, 2019). 
Asupan cairan rata-rata pada anak sekolah adalah $2.285 \mathrm{ml}$ pada siswa laki-laki dan $2.024 \mathrm{ml}$ pada siswa perempuan. Asupan cairan berasal dari makanan sekitar $20 \%$ atau 420-490 ml dan dari minuman $80 \%$ atau 1.600 $1.800 \mathrm{ml}$. Sebagian anak akan minum apabila sudah merasa haus padahal haus adalah tanda awal terjadinya dehidrasi (Briawan, Rachma, \& Annisa, 2011).

\section{METODE PENELITIAN}

Penelitian ini merupakan penelitian deskriptif analitik dengan desain cross sectional. Penelitian dilakukan pada bulan Juli-Agustus 2021 di Sekolah Dasar Negeri 2 Gembong, Kabupaten Pati. Populasi pada penelitian ini adalah semua anak SD kelas $4-6$ berjumlah 52 siswa. Pengambilan sampel menggunakan teknik total sampling dengan kriteria inklusi seluruh siswa kelas 4, 5, dan 6 dalam kondisi sehat. Kriteria eksklusi yang digunakan adalah anak yang sedang sakit dan tidak mau menjadi responden penelitian. Variabel penelitian adalah status nutrisi, status hidrasi, dan memori jangka pendek.

Definisi operasional dalam penelitian ini adalah:

1. status gizi, gambaran kondisi pemenuhan gizi anak diukur dari indeks massa tubuh menurut umur (IMT/U) anak usia 5 - 18 tahun. Anak ditimbang berat badan dan diukur tinggi badannya selanjutnya dihitung nilai IMT/U. Hasilnya gizi kurang = apabila hasil -3 s.d $<-2$ SD, gizi baik $=$ apabila hasil -2 s.d +1 SD, gizi lebih $=+1$ s.d +2 $\mathrm{SD}$, dan obesitas $\geq+2 \mathrm{SD}$;

2. status hidrasi adalah kondisi kecukupan jumlah cairan dalam tubuh yang ditentukan dengan mengukur berat jenis urine yang dilakukan di laboratorium dengan kategori tidak dehidrasi apabila nilai BJU <1,020gr/ dl dan dehidrasi apabila nilai BJU 1,020$1,030 \mathrm{gr} / \mathrm{dl}$;

3. memori jangka pendek yaitu kemampuan seseorang untuk mengingat suatu informasi yang baru biasanya dipertahankan selama sekitar 30 detik, menggunakan Digit Span penguji menyebutkan angka kemudian anak mengulangi kembali sesuai instruksi yang diberikan. Subtes Digit Span yang digunakan yaitu Digit Span Forward dan Digit Span Backward. Pemberian skor setiap subtes sebagai berikut

0 = apabila anak gagal lebih dari 2 kali percobaan, 1 = apabila anak hanya berhasil dalam 1 kali percobaan, 2 = apabila anak berhasil dalam 2 kali percobaan.

Tahap pengumpulan data dimulai dengan melakukan tes fungsi memori jangka pendek, mengukur tinggi badan serta berat badan, dan diakhiri dengan pengambilan sampel urine. Penghitungan IMT dilakukan untuk status gizi dan pemeriksaan urine untuk status hidrasi. Analisa data menggunakan uji Chi Square dengan tingkat kemaknaan $\mathrm{p} \leq 0,05$.

\section{HASIL DAN PEMBAHASAN}

Pengukuran dilakukan terhadap 52 anak siswa kelas 4, 5, dan 6, meliputi pengukuran fungsi memori jangka pendek, pengukuran tinggi badan dan berat badan, serta pengambilan sampel urine.

\section{Status Gizi Anak}

Hasil pengukuran status gizi disajikan pada Tabel 1. Sebagian besar responden $(69,2 \%)$ memiliki status gizi normal. Anak memiliki status gizi normal karena terpenuhinya asupan nutrisi. Hasil ini sejalan dengan penelitian di SMA Negeri 5 Kota Jambi yaitu 57,8\% siswa berstatus gizi normal yang artinya lebih dari separo siswa mempunyai status gizi normal (Merita, Aisah, \& Aulia, 2018). Penelitian di Sekolah Dasar Negeri 063 Pesisir Sungai Siak, Pekanbaru juga menunjukkan sebagian besar anak mempunyai status gizi normal $(73,9 \%)$. Namun demikian, masih ditemukan anak yang kurus dan sangat kurus sebanyak 7\% (Muchlis, Ernalia, \& Firdaus, 2015). Perbedaan status gizi pada anak dapat disebabkan oleh faktor asupan makanan. Asupan makanan yang kurang akan menyebabkan kebutuhan nutrisi anak tidak terpenuhi sehingga anak terlihat kurus dan sangat kurus. 
Tabel 1.

Status Gizi Anak Usia Sekolah di SD Negeri 2 Gembong, Kabupaten Pati

\begin{tabular}{lcc}
\hline Status Gizi & $\mathrm{n}$ & $\%$ \\
\hline Lebih & 5 & 9,7 \\
Normal & 36 & 69,2 \\
Kurang & 11 & 21,1 \\
Total & 52 & 100,0 \\
\hline
\end{tabular}

Sumber: Data Primer (2021)

Status gizi yang baik didukung beberapa faktor, antara lain penghasilan, pengetahuan tentang status gizi, pendidikan orang tua, karakterisktik orang tua, dan kebiasaan jajan (Nurrizka \& Wicaksana, 2019). Hasil penelitian terkait perilaku jajan pada anak sekolah dasar di Kabupaten Pati menyebutkan frekuensi jajan anak selama berada di sekolah minimal 1 kali dan terbanyak 2 kali atau lebih. Jajanan yang diminati anak adalah jajanan kemasan plastik atau kemasan pabrik. Jajanan tersebut belum terjamin keamanannya dari zat tambahan makanan. Kebiasaan jajan yang dilakukan oleh siswa disebabkan orang tua memberikan uang saku. Selain itu, para siswa juga beranggapan jajanan yang dibeli memiliki rasa yang lebih enak (Aini, 2019).

Anak yang mengalami obesitas atau gizi lebih disebabkan konsumsi makanan zat gizi makro yaitu karbohidrat, protein, dan lemak yang berlebih. Sekarang ini, anak-anak lebih menyukai aneka makanan siap saji, seperti sandwich, bakso, empek-empek, dan batagor. Makanan tersebut relatif memiliki kandungan karbohidrat tinggi yang selanjutnya meningkatkan kadar karbohidrat dalam tubuh menjadi lebih tinggi dibandingkan dengan anjuran normal konsumsi makanan (Raudha, Zahtamal, \& Ernalia, 2017).

Status gizi yang baik juga dipengaruhi oleh pola makan. Pola makan yang baik dapat mempertahankan status gizi yang baik. Hal ini selaras dengan hasil penelitian Sambo, Ciuantasari, \& Maria (2020) bahwa pola makan yang baik maka status gizinya baik sejumlah
$82,1 \%$. Jumlah makanan yang dikonsumsi juga menentukan status gizi anak. Jumlah makanan memiliki korelasi dengan status gizi anak. Jumlah makanan yang baik mendukung status gizi yang baik sejumlah 64,4\% (Panjaitan, Siagian, \& Hartono, 2019). Faktor lain yang memengaruhi status gizi adalah pengetahuan ibu dan asupan energi (Bertalina, 2017).

\section{Status Hidrasi}

Status hidrasi diklasifikasikan menjadi dua, yaitu dehidrasi dan tidak dehidrasi. Hasil pemeriksaan status hidrasi ditampilkan pada Tabel 2. Sebagian besar anak $(65,3 \%)$ memiliki status tidak dehidrasi. Anak tidak dehidrasi disebabkan asupan cairan terpenuhi. Hal ini sesuai dengan hasil penelitian bahwa asupan cairan pada anak rata - rata $2.074 \mathrm{ml}$ per hari. Adapun jenis cairan yang dikonsumsi adalah air putih, minuman lainnya, dan cairan dari makanan yang dikonsumsi. Konsumsi air putih lebih banyak dari pada minuman lain dan cairan dari makanan. Konsumsi cairan harian yang disarankan menurut Ikatan Dokter Anak Indonesia yaitu asupan cairan untuk anak usia 9-13 tahun adalah $2.400 \mathrm{ml}$ untuk anak laki-laki dan $2.100 \mathrm{ml}$ untuk anak perempuan (Prayitno \& Dieny, 2012).

Hasil penelitian lain menyebutkan terdapat perbedaan konsumsi cairan antara anak laki-laki dan perempuan. Konsumsi cairan lebih banyak jumlahnya pada anak laki-laki. Persentase kurang terhidrasi sebanyak 55\% terjadi pada anak perempuan (Widartika \& Gurid, 2017). Hal ini menunjukkan bahwa konsumsi cairan pada anak perempuan kurang.

Tabel 2.

Status Hidrasi Anak Usia Sekolah di SD Negeri 2 Gembong, Kabupaten Pati

\begin{tabular}{lcc}
\hline Status Hidrasi & $\mathrm{n}$ & $\%$ \\
\hline Dehidrasi & 18 & 34,7 \\
Tidak Dehidrasi & 34 & 65,3 \\
Total & 52 & 100,0 \\
\hline
\end{tabular}

Sumber: Data Primer (2021) 
Cairan sangat penting dalam membantu pertumbuhan dan perkembangan anak. Kebutuhan cairan setiap anak berbeda tergantung usia, jenis kelamin, massa otot, kadar lemak tubuh, serta daerah tempat tinggal. Anak usia prasekolah dan sekolah rata-rata minum 1.100 $\mathrm{ml}$ perhari yang seharusnya minimal $1.500 \mathrm{ml}$. Cairan bisa berasal dari minuman maupun makanan. Jenis cairan yang dapat dikonsumsi oleh anak adalah air putih atau air mineral dan susu. Jus buah sangat jarang dikonsumsi anak (Prawitasari dkk., 2020).

Minuman yang sehat untuk dikonsumsi anak saat berada di sekolah adalah minuman yang disiapkan sendiri seperti susu, teh, atau jus buah. Minuman tersebut dapat memenuhi kebutuhan cairan dan tidak mengandung bahan pengawet sehingga lebih aman dikonsumsi oleh anak. Anak memang membutuhkan cairan yang cukup, namun orang tua dan guru juga harus ikut memperhatikan minuman yang dikonsumsi anak (Briawan dkk., 2011).

Hasil penelitian ini berbeda dengan penelitian terhadap 10 partisipan anak usia sekolah yang menyimpulkan bahwa kecukupan air minum pada anak dalam kategori cukup sebanyak tiga anak dan kategori kurang ada tujuh anak. Temuan penelitian tersebut menunjukkan konsumsi air minum sebagian besar belum memenuhi jumlah anjuran harian (Kusumawardani \& Larasati, 2020).

Anak mengalami dehidrasi karena konsumsi cairan yang kurang. Hal tersebut kemungkinan disebabkan anak terlalu sibuk dengan aktivitasnya sehingga mengabaikan untuk minum (Bakri, 2019). Pemenuhan cairan tubuh dipengaruhi oleh pengetahuan anak dan orang tua tentang asupan cairan. Orang tua sebaiknya memperhatikan asupan cairan anak dan membiasakan anak untuk minum minuman yang berguna bagi pemenuhan kebutuhan cairan tubuh harian. Oang tua harus memberikan minuman tambahan saat ada peningkatan aktivitas anak, seperti olah raga, kondisi cuaca yang panas atau dingin, atau sedang berpuasa (Aprilia, 2017).

\section{Memori Jangka Pendek}

Pengukuran memori jangka pendek diklasifikasikan menjadi dua, yaitu normal dan menurun (Tabel 3). Hasil penelitian menunjukkan sebagian besar anak memiliki memori jangka pendek normal yaitu sebanyak $61,5 \%$. Memori jangka pendek merepresentasikan kemampuan anak dalam menahan informasi pada interval waktu yang singkat dan memiliki kapasitas yang sangat kecil dalam proses memori. Memori jangka pendek memiliki peran penting karena berfungsi dalam penyimpanan, transformasi, serta pemrosesan informasi untuk menghasilkan stimulus. Memori jangka pendek sangat dibutuhkan dalam mendukung memori jangka panjang (Bhinnety, 2008).

Penelitian oleh Mafatir, Sutadipura, \& Suryani (2019) menunjukkan bahwa anak usia sekolah memiliki memori jangka pendek yang optimal mencapai $69 \%$ dari keseluruhan anak dan tidak optimal 31\%. Sebagian besar anak mempunyai fungsi memori jangka pendek baik. Memori jangka pendek pada anak dapat ditingkatkan dengan berbagai upaya. Hasil penelitian menyebutkan ada peningkatan fungsi memori jangka pendek anak setelah diperdengarkan musik karawitan. Alunan musik yang lembut membuat anak lebih rileks dan mengurangi ketegangan sehingga dapat meningkatkan konsentrasi anak lebih baik (Julianto, 2017). Memori jangka pendek juga dapat ditingkatkan dengan rehearsal atau mengulang informasi secara verbal agar anak dapat mendengar dan memproses mengingat dengan waktu yang lebih lama yaitu lebih dari 30 detik. Tehnik rehearsal mampu meningkatan ingatan sesuai apa yang didengar (Suparmi, 2010).

Tabel 3.

Distribusi Frekuensi Memori Jangka Pendek Siswa SD Negeri 2 Gembong, Kabupaten Pati

\begin{tabular}{lcc}
\hline Memori Jangka Pendek & $\mathrm{n}$ & $\%$ \\
\hline Normal & 32 & 61,5 \\
Menurun & 20 & 38,5 \\
Total & 52 & 100,0 \\
\hline
\end{tabular}

Sumber: Data Primer (2021) 
Penggunaan gabungan indra, terutama penglihatan dan pendengaran mempermudah penyimpanan informasi dalam memori. Peningkatan memori jangka pendek menggunakan auditori mampu meningkatkan pencapaian akademik. Pesan yang dapat dilihat dan didengar akan diterima lebih baik dari pada menggunakan salah satu indra (Abraham, George, \& Kunnath, 2016). Struktur ingatan manusia terbagi menjadi tiga, yaitu perkembangan persepsi, daya ingat sesaat, dan memori jangka panjang. Memori mencatat semua pesan melalui panca indra (Bhinnety, 2008).

\section{Hubungan Status Gizi dengan Memori Jangka pendek}

Pengujian statistik menunjukkan nilai pvalue sebesar 0,04 , artinya terdapat hubungan status gizi dengan memori jangka pendek. Anak dengan status gizi yang baik akan memiliki memori jangka pendek yang normal. Sebaliknya, status gizi kurang menyebabkan memori jangka pendeknya kurang baik. Tabulasi silang antara status gizi dengan memori jangka pendek disajikan pada Tabel 4 .

Hasil penelitian ini sesuai dengan penelitian oleh Astina (2012), bahwa terdapat korelasi positif antara status gizi dengan kemampuan mengingat sesaat. Anak dengan status gizi normal akan memiliki kemampuan mengingat sesaat lebih baik. Anak dengan status nutrisi yang tidak normal yaitu lebih atau kurang lebih banyak menunjukkan memori jangka pendek mengalami penurunan.

Tabel 4.

Hubungan Status Nutrisi dengan Memori Jangka Pendek Siswa SD Negeri 2 Gembong,

\begin{tabular}{|c|c|c|c|c|c|}
\hline \multirow{3}{*}{$\begin{array}{c}\text { Status } \\
\text { Gizi }\end{array}$} & \multicolumn{4}{|c|}{ Memori Jangka Pendek } & \multirow{3}{*}{$\begin{array}{c}\mathrm{P} \\
\text { Value }\end{array}$} \\
\hline & \multicolumn{2}{|c|}{ Normal } & \multicolumn{2}{|c|}{ Menurun } & \\
\hline & $\mathrm{N}$ & $\%$ & $\mathrm{~N}$ & $\%$ & \\
\hline Lebih & 2 & 6,3 & 3 & 15 & \multirow{4}{*}{0,004} \\
\hline Normal & 25 & 78,1 & 11 & 55 & \\
\hline Kurang & 5 & 15,6 & 6 & 30 & \\
\hline Total & 32 & 100 & 20 & 100 & \\
\hline
\end{tabular}

Sumber: Data Primer (2021)
Status gizi sangat berpengaruh terhadap kerja otak. Energi dari makanan yang dikonsumsi dibutuhkan untuk mengoptimalkan otak. Teori yang disampaikan oleh Potter \& Perry (2010) bahwa nutrisi utama otak adalah glukosa. Makanan yang dikonsumsi terbanyak mengandung glukosa berasal dari karbohidrat. Apabila otak kekurangan glukosa, maka seseorang akan kesulitan berkonsentrasi dan kepala terasa pusing.

Sebaliknya hasil penelitian dari Saleh, Dharmmika, \& Tanuwidjaja (2020) ditemukan bahwa tidak ada perbedaan antara anak yang pendek dan tinggi. Anak stunting bermasalah pada pertumbuhan yang mungkin saja bukan dikarenakan asupan nutrisi yang kurang namun dari faktor sistem endokrin yang bermasalah.

Berdasarkan Tabel 4, terlihat anak dengan status gizi lebih juga akan mengalami masalah pada memori jangka pendeknya. Berdasarkan penelitian Hartini \& Winarsih (2014), diketahui bahwa anak-anak yang mengalami peningkatan berat badan maka terjadi penurunan memori jangka pendeknya. Anak yang obesitas mengalami penurunan memori jangka pendek sebesar 52,9\%. Obesitas menyebabkan peningkatan kadar kolesterol dalam darah yang akan menghambat proses pengiriman nutrisi ke otak.

Asupan nutrisi berpengaruh terhadap kemampuan anak dalam menerima informasi dan menyimpannya dalam ingatan. Asupan makanan lebih baik diberikan pada saat sebelum melakukan aktivitas yang membutuhkan konsentrasi. Sebelum berangkat sekolah sebaiknya anak sudah makan pagi atau sarapan terlebih dahulu sehingga persediaan energi terpenuhi. Hasil penelitian lain tentang adanya hubungan kebiasaan sarapan dengan tingkat memori pada anak sekolah dasar. Anak yang sarapan sebelum melaksanakan aktivitas sekolah mempunyai memori lebih tinggi dibandingkan dengan anak yang tidak terbiasa sarapan (Aryadi, Ariawati, \& Suwarba, 2019).

Nutrisi merupakan elemen atau komponen yang diperlukan tubuh untuk digunakan tubuh dalam proses dan menjalankan fungsi 
organ di dalam tubuh. Kebutuhan energi dapat diperoleh dari berbagai zat makanan, seperti hidrat arang, protein, lemak, air, vitamin dan mineral. Pemenuhan kebutuhan nutrisi bukan dilihat dari jumlah makanannya namun dilihat dari komposisinya. Karbohidrat merupakan bahan bakar utama untuk otak, otot rangka, dan produksi eritrosit (Berman et al., 2018).

Hasil penelitian menunjukkan sebagian kecil anak memiliki masalah dengan status nutrisi, namun memori jangka pendeknya tetap baik. Kondisi tersebut dimungkinkan karena terdapat faktor selain nutrisi yang berpengaruh terhadap memori. Menurut Lestari (2013), faktor yang memengaruhi memori jangka pendek adalah motivasi dan lingkungan sekitar. Lingkungan sekitar yang mendukung untuk berkonsentrasi maka anak akan mudah mengingat apa yang dia dengar dan lihat.

\section{Hubungan Status Hidrasi dengan Memori Jangka Pendek}

Hasil uji statistik menunjukkan nilai pvalue sebesar 0,02 , artinya terdapat hubungan status hidrasi dengan memori jangka pendek. Anak yang tidak dehidrasi memiliki memori jangka pendek yang baik. Tabulasi silang antara status hidrasi dengan memori jangka pendek disajikan pada Tabel 5. Hasil studi ini sejalan dengan penelitian sebelumnya yang menunjukkan terjadi penurunan daya ingat segera pada anak yang mengalami kekurangan cairan pada tubuh dengan nilai Nonparametric Coreelation's Sprearman $\mathrm{P}=0,004$. Dehidrasi berpengaruh terhadap fungsi kognitif, performa, dan mood (Bahrudin \& Nafara, 2019).

Tabel 5.

Hubungan Status Hidrasi dengan Memori Jangka Pendek Siswa SD Negeri 2 Gembong,

\begin{tabular}{lccccc}
\hline \multirow{2}{*}{ Status Hidrasi } & \multicolumn{2}{c}{ Memori Jangka Pendek } & \\
\cline { 2 - 4 } & \multicolumn{2}{c}{ Normal } & \multicolumn{2}{c}{ Menurun } & Value \\
\cline { 2 - 4 } & $\mathrm{N}$ & $\%$ & $\mathrm{~N}$ & $\%$ & \\
\hline Dehidrasi & 5 & 15,6 & 13 & 65 & \\
Tidak Dehidrasi & 27 & 84,4 & 17 & 35 & 0,002 \\
Total & 32 & 100 & 20 & 100 & \\
\hline
\end{tabular}

Sumber: Data Primer (2021)
Anak lebih mudah mengalami dehidrasi dibandingkan dengan orang dewasa. Anak dan remaja yang mengalami dehidrasi ringan akan mudah kehilangan mood, namun masih bisa berkonsentrasi masih baik. Kondisi ini terjadi karena dehidrasi yang dialami masih bisa ditoleransi oleh tubuh, sehingga tubuh masih mampu menyeimbangkan cairan tubuh (Lentini \& Margawati, 2014).

Komposisi cairan dalam tubuh mencapai $60-70 \%$ dari seluruh tubuh. Keseimbangan cairan menjadi bagian dari mekanisme keseimbangan atau homeostatis tubuh. Untuk menjaga homestatis, tubuh perlu mengatur dan mempertahankan cairan ekstraseluler dengan cara mengatur input dan output cairan. Apabila asupan cairan berkurang dalam waktu singkat, tubuh masih mampu menyeimbangkan cairan intraseluler dan ektraseluler. Namun, apabila asupan cairan berkurang dalam waktu yang lama maka tubuh tetap akan kekurangan cairan dan berdampak pada terhambatnya sistem sirkulasi (William, 2017).

Hasil penelitian ini diperkuat penelitian sebelumnya tentang pemberian air mineral dengan memori jangka pendek anak. Hasil penelitian tersebut menunjukkan terdapat perbedaan memori jangka pendek anak antara sebelum dan sesudah diberi air minum. Terjadi peningkatan jumlah siswa yang fungsi memorinya baik setelah minum air mineral $200 \mathrm{ml}$ (Winarsih et al., 2020).

Penelitian serupa di SD Darul Hikam International menyebutkan bahwa memori jangka pendek siswa dan siswi setelah diberikan air mineral terjadi peningkatan dibandingkan dengan sebelum diberi air mineral. Kecukupan cairan tubuh memicu reaktivasi kardiovaskuler sehingga terjadi peningkatan perfusi atau aliran darah ke otak. Hal ini akan mempengaruhi fungsi kognitif anak (Mafatir dkk., 2019). Air berperan penting bagi tubuh. Kekurangan cairan tubuh dapat mengakibatkan gangguan fungsi kognitif. Otak yang mengalami kekurangan cairan akan menstimulasi pengeluaran sistem renin angiotensin dan prostalglandin. 
Akibatnya adalah terjadi peningkatan vasopressin arginin yang memicu peningkatan kortisol. Hiperkortisol bisa menyebabkan gangguan proses studi, proses memori jangka pendek dan memori secara lisan (Asiah, 2013).

Hasil penelitian lainnya menyebutkan memori jangka pendek anak usia sekolah dipengaruhi oleh latihan fungsi motorik dan fungsi kognitif (Lestari, 2013). Adanya latihan ini akan membuat aktivasi neural yang lebih baik (Mendel, Barbosa, \& Sasaki, 2015). Hasil penelitian juga menunjukkan adanya anak yang mengalami dehidrasi namun memori jangka pendek normal $(15,6 \%)$. Selain itu, ada juga anak yang tidak dehidrasi namun mengalami penurunan memori. Hal tersebut mungkin disebabkan karena kemampuan memori anak dipengaruhi oleh sebab lain. Kekurangan cairan sesaat sehingga belum mempengaruhi terhadap konsentrasi anak. Tubuh melakukan kompensasi dengan meningkatkan reabsorsi cairan (Arinda, 2016).

Tujuan pemenuhan kebutuhan cairan tubuh pada anak untuk menunjang memori jangka pendek yang baik. Oleh karena itu, anak juga harus tahu fungsi dari minum air sesuai kebutuhan tubuh. Apabila anak memiliki pengetahuan yang baik maka anak mampu dan mau mempraktikkan pemenuhan minum air untuk dirinya sendiri. Anak akan lebih selektif dalam memilih makanan dan minuman yang sehat. Kebutuhan cairan tubuh terpenuhi akan meningkatkan konsentrasi anak dalam melakukan aktivitas di sekolah maupun di rumah (Sari, 2014).

Anak perlu diberikan stimulasi untuk meningkatkan kemampuan memori. Stimulasi dapat dilakukan oleh orang tua dan guru. Beberapa jenis stimulasi untuk peningkatan memori, seperti diminta untuk menceritakan suatu yang penah dilihat secara detail, memberikan permainan untuk mengasah memori, membuat strategi untuk mengingat dengan menggunakan simbol-simbol, membagi tugas dan mengerjakan pada bagian yang sulit, dan terakhir memberikan banyak latihan untuk mengulangi angka-angka (Nurlaila, 2019).
Bentuk permainan edukatif yang banyak diberikan kepada anak adalah senam otak. Anak yang melakukan senam otak terbukti mengalami peningkatan daya ingat. Senam otak dapat menstimulasi seluruh bagian otak dan mengembangkan kerja otak kanan dan kiri secara sinergis. Hal tersebut didukung dengan asupan makanan dan minuman yang sesuai kebutuhan dan usia anak (Agustin, 2020). Pemberian informasi tentang pentingnya konsumsi cairan perlu disertai dengan upaya penyiapan air minum akan berpengaruh terhadap anak maupun remaja untuk meningkatkan asupan minum air (Arinda, 2016).

\section{KESIMPULAN DAN SARAN}

\section{Kesimpulan}

Hasil penelitian menunjukkan sebagian besar anak memiliki status gizi normal $(69,2 \%)$. Masih terdapat anak dengan status gizi kurang dan lebih yang menjadi kondisi malnutrisi. Sebagian besar anak tidak mengalami dehidrasi $(65,3 \%)$. Selain itu, sebagian besar anak memiliki memori jangka pendek yang normal (61,5\%). Terdapat hubungan status gizi dengan fungsi memori jangka pendek dengan nilai pvalue 0,004 . Anak yang memiliki status gizi yang baik akan memiliki memori jangka pendek yang normal. Terdapat hubungan status hidrasi dengan fungsi memori jangka pendek dengan nilai pvalue 0,002 . Anak yang tidak dehidrasi memiliki memori jangka pendek yang baik. Kondisi malnutrisi dan dehidrasi berpengaruh terhadap memori jangka pendek anak.

\section{Saran}

Upaya untuk untuk meningkatkan memori jangka pendek adalah: 1) pemenuhan asupan nutrisi anak dengan mengatur pola makan. Kualitas dan kuantitas makanan perlu diperhatikan agar status gizi anak tidak berlebihan atau kurang, 2) pemenuhan cairan diperlukan untuk menjaga sirkulasi cairan tubuh pada kondisi baik sehingga fungsi tubuh dapat berfungsi dengan baik, 3) pemberian stimulasi pada anak 
untuk meningkatkan kemampuan motorik dan kognitif ditunjang lingkungan yang kondusif. Oleh karena itu, orang tua dan guru perlu memperhatikan kebutuhan nutrisi dan cairan anak baik di rumah maupun di sekolah.

\section{UCAPAN TERIMA KASIH} kepada:

Ucapan terima kasih disampaikan peneliti

1. Kemenristek/BRIN yang telah mendanai penelitian ini berdasarkan Kontrak Penelitian No.2/063057/PG/SP2H/ TD/2021;

2. Kepala LPPM STIKES Cendekia Utama Kudus yang membantu proses penyelesaian proposal, memfasilitasi pengajuan proposal, dan mengarahkan jalannya penelitian sampai proses publikasi hasil penelitian;

3. Kepala sekolah beserta guru kelas 4, 5 dan 6 di SD N 2 Gembong Pati yang memfasilitasi proses penelitian.

\section{DAFTAR PUSTAKA}

Abdullah, A., \& Norfai, N. (2019). Analisis Status Gizi dengan Prestasi Belajar pada Siswa di SDN Mawar 8 Kota Banjarmasin. Jurnal Kesehatan Indonesia, 9(2), 53-58.

Abraham, A., George, V. M., \& Kunnath, S. (2016). Auditory Short Term Memory and Academic Achievement in Normal School Going Children. International Journal of Health Sciences \& Research, 6(1), 480-483.

Agustin, A. R. C. L. (2020). Pengaruh Senam Otak Terhadap Daya Ingat Anak Usia Sekolah di Sekolah Dasar Negeri 1 Upai Kotamobagu Utara Kota Kotamobagu Community of Publishing In Nursing (COPING), 8(4), 394-400.

Aini, S. Q. (2019). Perilaku Jajan pada Anak Sekolah Dasar. Jurnal Litbang: Media Informasi Penelitian, Pengembangan dan IPTEK, 15(2), 133-146. https:// doi.org/10.33658/jl.v15i2.153
Aprilia, D. R. (2017). Gambaran Asupan Air Minum dan Tingkat Pengetahuan Cairan pada Siswa Kelas VII Sekolah Menengah Pertama Kristen Immanuel II Kubu Raya. (Karya Tulis Ilmiah). Pontianak: Poltekes Kemenkes

Apriyanto, D. (2014). Pengaruh Metode Pembelajaran Mind Mapping dan Kemampuan Memori Siswa Terhadap Prestasi Belajar Kimia pada Pokok Bahasan HukumHukum Dasar Kimia pada Siswa Kelas X Semester Gasal di SMA Negeri 1 Mojolaban Tahun Pelajaran 2012/2013. Jurnal Pendidikan Kimia (JPK), 3(3):1-10

Arinda, D. F. (2016). Pengaruh Edukasi dan Pemberian Air Minum Terhadap Tingkat Konsumsi Air Minum, Status Hidrasi, dan Performa Kognitif (Konsentrasi dan Memori Jangka Pendek) Remaja (Thesis). Universitas Gadjah Mada, Fakultas Kedokteran.

Aryadi, I. P. H., Ariawati, K., \& Suwarba, I. G. N. M. (2019). Hubungan antara Kebiasaan Sarapan dengan Tingkat Memori pada Siswa Sekolah Dasar Negeri di Kota Denpasar. Media Penelitian dan Pengembangan Kesehatan, 29(3), 197-204.

Asiah, N. (2013). Air dan Gangguan Fungsi Kognitif. Majalah Kesehatan Pharmamedika, 5 (1). : 38-43 https://doi.org/10.33476/ mkp.v5i1.1101

Astina, J. (2012). Pengaruh status Gizi dan Status Anemia Terhadap Daya Ingat Sesaat Siswa di SDN Pasanggrahan 1 Kabupaten Purwakarta. Jurnal Gizi dan Pangan, 7(2), 103-110.

Bahrudin, M., \& Nafara, A. B. (2019). Hubungan Dehidrasi Terhadap Memori Segera/ Atensi. Saintika Medika, 15(1), 12-24.

Bakri, S. (2019). Status Gizi, Pengetahuan, dan Kecukupan Konsumsi Air pada Siswa SMA Negeri 12 Kota Banda Aceh. AcTion: Aceh Nutrition Journal, 4(1), 22-27. 
Berman, A., Snyder, S. J., Levett-Jones, T., Dwyer, T., Hales, M., Harvey, N., Reid-Searl, K. (2018). Kozier and Erb's Fundamentals of Nursing [4th Australian edition]. In: Pearson Australia.

Bertalina, B. (2017). Faktor-Faktor yang Berhubungan dengan Status Gizi Anak Usia Sekolah (6-12 Tahun) Jurnal Ilmiah Keperawatan Sai Betik, 9(1), 5-12.

Bhinnety, M. (2008). Struktur dan Proses Memori. Buletin Psikologi, 16(2) :74-88

Briawan, D., Rachma, P., \& Annisa, K. (2011). Kebiasaan Konsumsi Minuman dan Asupan Cairan pada Anak Usia Sekolah di Perkotaan. Jurnal Gizi dan Pangan, 6(3), 186-191.

Bujuri, D. A. (2018). Analisis Perkembangan Kognitif Anak Usia Dasar dan Implikasinya dalam Kegiatan Belajar Mengajar. LITERASI (Jurnal Ilmu Pendidikan), 9(1), 37-50.

Desmita, D. (2009). Psikologi Perkembangan Peserta Didik. Bandung: Remaja Rosdakarya.

Hartini, S., \& Winarsih, B. D. (2014). Analisis Pengaruh Berat Badan Lebih Terhadap Penurunan Fungsi Memori Jangka Pendek pada Anak Umur 8-12 Tahun di SD Cahya Nur Kabupaten Kudus. Jurnal Keperawatan dan Kesehatan Masyarakat Cendekia Utama, 3(2): 41-49. https:// doi.org/10.31596/jcu.v1i3.51.

Hastjarjo, D. (2008). Kajian Tentang Memori. Buletin Psikologi, 16(2). https://doi.org/ 10.22146/bpsi.7374.

Julianto, V. (2017). Meningkatkan Memori Jangka Pendek dengan Karawitan. Indigenous: Jurnal Ilmiah Psikologi, 2(2). https://doi.org/10.23917/ indigenous.v2i2.5451.

Kusumawardani, S., \& Larasati, A. (2020). Analisis Konsumsi Air Putih Terhadap Konsentrasi Jurnal Holistika, 4(2), 91-95.

Lentini, B., \& Margawati, A. (2014). Hubungan Kebiasaan Sarapan dan Status Hidrasi dengan Konsentrasi Berfikir pada Remaja. Journal of Nutrition College, 3(4), 631637.
Lestari, O. (2013). Analisis Pengaruh Audio Visual Terhadap Kemampuan Memori Jangka Pendek pada Kelompok Usia Produktif Berdasarkan Tingkat Pendidikan. (Makalah Penelitian Tugas Akhir). Yogyakarta: Universitas Pembangunan Nasional Veteran Yogyakarta

Mafatir, M. S., Sutadipura, N., \& Suryani, Y. D. (2019). Hubungan Antara Pemberian Air Mineral dengan Memori Jangka Pendek Anak Kelas 5 Sekolah Dasar Daarul Hikam International School, Bandung. Prosiding Kedokteran, Universitas Islam Bandung.

Maulina, R. R., Subekti, S., \& Yulia, C. (2019). Analisis Kualitas Diet Siswa Sekolah Dasar Kreatif Harapan Bangsa. Media Pendidikan, Gizi, dan Kuliner, 9(1).

Mendel, T., Barbosa, W. O., \& Sasaki, A. C. (2015). Dual task training as a therapeutic strategy in neurologic physical therapy: a literature review. CEP, 41810, 480 .

Merita, M., Aisah, A., \& Aulia, S. (2018). Status Gizi Dan Aktivitas Fisik dengan Status Hidrasi pada Remaja di SMA Negeri 5 Kota Jambi. Jurnal Ilmu Kesehatan Masyarakat, 9(3), 207-215.

Mu'min, S. A. (2013). Teori Perkembangan Kognitif Jean Piaget. Al-TA'DIB: Jurnal Kajian Ilmu Kependidikan, 6(1), 89-99.

Muchlis, M., Ernalia, Y., \& Firdaus, F. (2015). Hubungan Status Gizi dengan Prestasi Belajar Siswa Sekolah Dasar Negeri 063 di Pesisir Sungai Siak Kecamatan Rumbai Pesisir Kota Pekanbaru. JOM FK, 3 (1), 110.

Musdalifah, R. (2019). Pemrosesan dan Penyimpanan Informasi pada Otak Anak dalam Belajar: Short Term and Long Term Memory. AL-ISHLAH: Jurnal Pendidikan Islam, 17(2), 217-235.

Ningtyas, D. P. (2018). Peningkatan Kemampuan Memori Anak Pada Konsep Angka Melalui Permainan Ular Tangga. AWLADY: Jurnal Pendidikan Anak, 4(2), 180-194. 
Nurlaila, A. (2019). 5 Siasat Tingkatkan Kemampuan Memori Anak. Berita Perkembangan Anak. Retrieved from "https:// www.medcom.id/rona/ keluarga/3NOXYmpb-5-siasat-tingkatkan -kemampuan-memori-anak".

Nurrizka, R. H., \& Wicaksana, D. A. (2019). Faktor-Faktor yang Berhubungan dengan Status Gizi pada Anak Usia Sekolah di SDN Bedahan 02 Cibinong Kabupaten Bogor Tahun 2018. JURNAL ILMIAH KESEHATAN MASYARAKAT: Media Komunikasi Komunitas Kesehatan Masyarakat, 11(1), 35-48.

Palupi, E., Sulaeman, A., \& Ploeger, A. (2013). World Hunger, Malnutrition and Brain Development of Children.

Panjaitan, W. F., Siagian, M., \& Hartono, H. (2019). Hubungan Pola Makan dengan Status Gizi pada Anak Sekolah Dasar Al Hidayah Terpadu Medan Tembung. Jurnal Dunia Gizi, 2(2), 71-78.

Pertiwi, D. (2015). Status Dehidrasi Jangka Pendek Berdasarkan Hasil Pengukuran Puri (Periksa Urin Sendiri) Menggunakan Grafik Warna Urin pada Remaja Kelas 1 dan 2 di SMAN 63 Jakarta Tahun 2015. (Skripsi). Jakarta: UIN Syarif Hidayatullah Jakarta.

Potter, P. A., \& Perry, A. G. (2010). Fundamental Keperawatan (7 ed. Vol. 2). Mosby: Elvisier.

Prasetyo, W., \& Saputra, S. A. (2017). Pengaruh Senam Otak Terhadap Daya Ingat Anak Kelas V Sekolah Dasar. Jurnal Keperawatan, 6(1), 36-40.

Prawitasari, T., Medise, B. E., Sunardi, D., Friska, D., Prafiantini, E., Pohan, R. Y., \& Wiweko, B. (2020). Profil Asupan Minum pada Anak Prasekolah di Daerah Urban dan Rural di Indonesia dan Faktor-Faktor yang Memengaruhinya. Sari Pediatri, 22 (4), 236-242.

Prayitno, S. O., \& Dieny, F. F. (2012). Perbedaan konsumsi Cairan dan Status Hidrasi pada Remaja Obesitas dan Non Obesitas. Journal of Nutrition College. 1(1): 144-152.
Putranto, P. L. (2009). Pengaruh Senam Otak terhadap Fungsi Memori Jangka Pendek Anak dari Keluarga Status Ekonomi Rendah. (Tesis). Universitas Diponegoro, Program Pasca Sarjana Magister Ilmu Biomedik.

Rahmawati, T., \& Marfuah, D. (2016). Gambaran Status Gizi pada Anak Sekolah Dasar. Profesi (Profesional Islam): Media Publikasi Penelitian, 14(1), 72-76.

Raudha, U., Zahtamal, Z., \& Ernalia, Y. (2017). Gambaran Nilai Gizi Makanan yang Dikonsumsi oleh Remaja Obesitas di Sekolah. 4(2), 1-13. https:// jom.unri.ac.id/index.php/JOMFDOK/ article/view/15493/15035.

Saleh, A. S., Dharmmika, S., \& Tanuwidjaja, S. (2020). Hubungan Stunting dengan Memori Jangka Pendek pada Siswa Usia Sekolah Dasar Kelas 1-6 di SDN Panyirapan 01 Kabupaten Bandung Tahun 2019. Prosiding Kedokteran, Universitas Islam Bandung.

Sambo, M., Ciuantasari, F., \& Maria, G. (2020). Hubungan Pola Makan dengan Status Gizi pada Anak Usia Prasekolah. Jurnal Ilmiah Kesehatan Sandi Husada, 9(1), 423-429.

Santoso, B. I., Siregar, P., \& Pardede, S. O. (2011). Air bagi Kesehatan. Bogor: Centra Comunications.

Sari, I. P. T. P. (2014). Tingkat Pengetahuan Tentang Pentingnya Mengkonsumsi Air Mineral Pada Siswa Kelas IV SD Negeri Keputran A Yogyakarta. Jurnal Pendidikan Jasmani Indonesia, 10(2):55-61.

Sari, W., Rosya, E., \& Wahyuni, Y. (2019). Gerakan AMIR (Ayo Minum Air) untuk Cegah Dehidrasi Anak Usia Sekolah di SD Negeri 011 Kelurahan Duri Kepa Jakarta Barat Tahun 2019. (Laporan Akhir Program Pengabdian Masyarakat). Jakarta: Universitas Esa Unggul.

Sudrajat, A., Mexitalia, M., \& Rosidi, A. (2019). Status Hidrasi, Tingkat Kebugaran Jasmani dan Daya Konsentrasi Anak Sekolah Dasar. Jurnal Gizi Indonesia (The Indonesian Journal of Nutrition), 7(2), 109-113. 
Suparmi, S. (2010). Studi Meta Analisa: Strategi Rehearsal dan Memori Jangka Pendek. Jurnal Psikologi Tabularasa, 5(2):289310.

Widartika, \& Gurid, P. (2017). Hubungan Antara Konsumsi Cairan, Kegemukan, dan Status Hidrasi pada Remaja di SMP Negeri 1 Banjaran Bandung. Jurnal Riset Kesehatan Poltekes Depkes Bandung, 10(1), 9-19. https://doi.org/10.34011/ juriskesbdg.v10i1

William, W. (2017). Fisiologi Keseimbangan Cairan dan Hormon yang Berperan. Jurnal Kedokteran Meditek, 23(61), 69-73. https://doi.org/10.36452/

jkdoktmeditek.v23i61

Winarsih, B. D., Fatmawati, Y., \& Hartini, S. (2020). Pengaruh Pemberian Air Mineral Terhadap Fungsi Memori Jangka Pendek Anak Usia Sekolah di SD N 2 Gembong Pati The Shine Cahaya Dunia Ners, 5(2): 17-27. https://doi.org/10.35720/ tscners.v5i2

Wiyono, S., \& Harjatmo, T. P. (2019). Penilaian Status Gizi. Litbang Kemkes.

Wong, D. L. (2009). Buku Ajar Keperawatan Pediatrik. ed. 6. alih bahasa Dr. Andri Hartono. Jakarta: EGC.

Yuliati, E., Kandarina, B. I., \& Sudargo, T. (2018). Pengaruh Promosi Gizi di Sekolah Terhadap Pengetahuan, Sikap, dan Perilaku Tentang Konsumsi Air pada Anak Sekolah Dasar di Kota Yogyakarta. Ilmu Gizi Indonesia, 2(1), 13-24.

\section{BIODATA PENULIS}

Biyanti Dwi Winarsih, lahir pada tanggal 7 September 1978 di Kudus. Magister Keperawatan dari Universitas Indonesia. Bekerja sebagai dosen pada Program Studi Profesi Ners, Sekolah Tinggi Ilmu Kesehatan Cendekia Utama Kudus

Yayuk Fatmawati, lahir pada tanggal 4 September 1980 di Kudus. Magister Keperawatan dari Universitas Gajah Mada. Bekerja sebagai dosen pada Program Studi S1 Ilmu Keperawatan, Sekolah Tinggi Ilmu Kesehatan Cendekia Utama Kudus

Sri Hartini, lahir pada tanggal 1 Maret 1978 di Demak. Magister Kesehatan dari Universitas Diponegoro. Bekerja sebagai dosen pada Program Studi Profesi Ners, Sekolah Tinggi Ilmu Kesehatan Cendekia Utama Kudus 
Hubungan Status Gizi dan ...

Winarsih, Fatmawati, \& Hartini 